\title{
Protect High Seas Biodiversity
}

The high seas - marine areas beyond national jurisdiction (1) — cover nearly half of Earth's surface (2). The high seas support our planet in countless ways, from regulating the climate, to feeding millions of people, to supporting industries that contribute billions of dollars to the global economy (3). Even so, less than $1 \%$ of the high seas are fully protected (4), and the current patchwork of management and lack of oversight leaves them vulnerable to abuse. In 2017, the United Nations resolved to develop an international treaty for the conservation and sustainable use of the high seas. Negotiations are set to end in 2021. We must ensure that the forthcoming framework conserves high-seas biodiversity and promotes sustainable and equitable use.

To maximize biodiversity protection beyond national jurisdiction, the high seas treaty should incorporate the timely establishment of a network of fully protected marine protected areas for diverse habitats in strategic locations. Fully protected marine reserves in the open ocean preserve fish populations, protect fragile and valuable ecosystems, and increase ecosystem resilience (5, 6). Implementing effective marine protected areas will require a coordinated approach across existing regional and sectoral bodies and the scientific community $(6,7)$.

The treaty should also provide a robust framework to assess the environmental impacts of activities on the high seas. Such evaluations should use comprehensive and rigorous global standards and transparent monitoring. Where necessary, existing assessment processes should be reimagined to better measure cumulative impacts. Because the high seas are dynamic and poorly understood, strategic environmental assessments will be required to design effective policies in the future (7).

Finally, the treaty should establish a robust institutional framework that will enable the successful implementation of these safeguards. At a minimum, the changes will require an administrative body, a decisionmaking body, a scientific committee with influence over decision-making, and a compliance committee. All activities, decisions, and plans should be open and transparent.

Every year, vulnerable and under-studied marine ecosystems are substantially, and in some cases permanently, altered by human activities $(8,9)$. The proposed treaty provides an opportunity to conserve the high seas for generations to come and create a more equitable ocean for all humankind $(10,11)$. We call on all nations to construct an ambitious treaty and conclude these negotiations as soon as possible, to finally put legal protection in place for the unprotected half of our planet (12).

\section{\#\#\#}

Scientists who wish to support this Letter can add their signature here: protectthehighseas.com 


\section{AUTHORS}

1. Rebecca R. Helm - University of North Caroline Asheville; Smithsonian Institution National Museum of Natural History, USA

2. Nichola Clark - Australian National Centre for Ocean Resources and Security, University of Wollongong, Australia; The Pew Charitable Trusts, USA

3. Harriet Harden-Davies - Australian National Centre for Ocean Resources and Security, University of Wollongong, Australia; Woods Hole Oceanographic Institution, USA

4. Diva Amon - SpeSeas, Trinidad and Tobago; Natural History Museum, UK

5. Peter Girguis - Harvard University; Woods Hole Oceanographic Institution, USA

6. Cesar Bordehore - University of Alicante, Spain

7. Sylvia Earle - Mission Blue, USA

8. Mark J Gibbons - University of the Western Cape, South Africa

9. Yimnang Golbuu - Palau International Coral Reef Center, Palau

10. Steven H. D. Haddock - Monterey Bay Aquarium Research Institute, USA

11. Jonathan D. R. Houghton - Queen's University Belfast, Northern Ireland

12. Jamileh Javidpour - University of Southern Denmark, Denmark

13. Douglas McCauley - University of California Santa Barbara, USA

14. Lance Morgan - Marine Conservation Institute, USA

15. David Obura - CORDIO East Africa, Kenya

16. Evgeny A. Pakhomov - University of British Columbia, Canada

17. Kylie A. Pitt - Griffith University, Australia

18. Jorge Jimenez Ramon - MarViva, Costa Rica

19. Rashid Sumaila - University of British Columbia, Canada

20. Jean-Baptiste Thiebot - National Institute of Polar Research, Japan

\section{REFERENCES AND NOTES}

1. United Nations, Intergovernmental Conference on Marine Biodiversity of Areas Beyond National Jurisdiction, Fourth Session of the Intergovernmental Conference (www.un.org/bbnj/).

2. G. Wright, J. Rochette, K. M. Gjerde, L. A. Levin, Nature 554, 163 (2018).

3. E. Sala et al., Nature 592, 397 (2021).

4. Marine Conservation Institute, Marine Protection Atlas (2021); https://mpatlas.org/countries/HS.

5. E. Sala, S. Giakoumi, J. Mar. Sci. 75, 1166 (2017).

6. M. E. Visalli et al., Mar. Pol. 122, 103927 (2020).

7. N. C. Ban et al., Conserv. Lett. 7, 41 (2014).

8. B. S. Halpern et al., Nat. Commun. 6, 1 (2015).

9. E. Ramirez-Llodra et al., PLOS One 6, e22588 (2011).

10. D. J. McCauley et al., Sci. Adv. 4, eaau2161 (2018).

11. U. R. Sumaila et al., Sci. Rep. 5, pp.1-6. 2015 